\title{
The Role of Employee's Work Expectations in Job Satisfaction and Labour Turnover in the Service Industry: A Case of Selected Organisations in Lagos, Ogun and Oyo States Nigeria
}

\author{
Oginni, Babalola Oluwayemi (Corresponding author) \\ Department of Economics and Business Studies \\ Redeemer's University, Ede Osun State, Nigeria \\ isomes2011@gmail.com \\ Dunmade, Emmanuel Olaniyi \\ Department of Business Administration \\ Federal University of Technology, Akure, Ondo State, Nigeria \\ E-mail: niyidunmade@yahoo.co.uk \\ Ogunwole Aina Cecilia \\ Department of Internal Audit, University of Ibadan \\ Oyo State, Nigeria
}

Received: November 10, 2017

Accepted: March 8, 2018 Published: March 30, 2018

doi:10.5296/wjbm.v4i1.12924

URL: https://doi.org/10.5296/wjbm.v4i1.12924

\begin{abstract}
The study aimed at investigating the role of employee's work expectations in job satisfaction and implication on labour turnover in the service industry in some selected organisations in the three states of Western part of Nigeria. The study identified some elements of employee's work expectations as well as the relationship between and among the variables of the study. A total number of 593 copies of questionnaires were randomly administered to the respondents from which 571 copies were collected back from the respondents out of which 542 copies of questionnaires were found useful for analytical purposes thus giving response rate as $91 \%$. Correlation and regression analyses were used to determine the relationship and test the stated
\end{abstract}




\section{Macrothink}

World Journal of Business and Management

ISSN 2377-4622

2018, Vol. 4, No. 1

hypotheses. It was found that there is a positive and strong relationship among the variables at 0.05 level of significance. It was recommended that management of the service industry should endeavour to utilise interview as a weapon during employment process to understand the work expectations of the employees and place side by side with that of employer's expectations and give the job to the most suitable candidate and not the best candidate whose work expectation is not congruent with that of the employer.

Keywords: Work expectations, Job satisfaction, Labour turnover, Nigeria, Unemployment 


\section{Introduction}

All over the world with no exception to continent, region, country or race, the concept of business organisation is believed to embrace employee and employer as the main actors with government as a regulator of the relationship between the main actors (Oginni \& Faseyiku, 2012). In views of Greene in Ayinla (2006), emerging from the employee-employer relationship in the workplace is contractual expectations where employee expects the resultant of work activities to meet his or her needs and be identified with the organisation till retirement while employer expects loyalty and hard work till retirement. However, the incidents in today's business climate of rapid change as characterised by dynamism and uncertainty have implication on the contractual expectations as evidenced in the views of Adebanjo (2009), that the unemployment situation and the rate of technological advancement in Nigeria have made the work expectations of Nigerian workers to be vague as many do not fully understood what they expect at work. Work expectations are those things people consider likely to happen in their job situation either now or in the future (Balogun, 2004). Whether spoken or unspoken, met or unmet, expectations have a significant effect on thoughts, feelings, and behaviours as well as playing key role in driving attitudes to meet reality towards meeting business objectives. In a typical work employment situation of any given organisation, there are usually certain expectations that are clearly understood by both employer and employee (Adeoye, 2005). These certain expectations may be visible, expressed or implied. The visible ones include wages and salary, hours of operations, duties and responsibilities as well as rules and regulations designed to guild the relationship in form of interaction between the employer and employee with cumulative effect on the level of job satisfaction and labour turnover (Adeoye, 2005). The expressed and implied expectations are other expectations that are intimately linked to individual's level of experience and concept of work that often go unspoken or acknowledged thus, giving room for miscommunication, misunderstanding and sometimes conflict (Adeoye \& Williams, 2007). The difference in the level of expectations is deeply rooted in individual difference as postulated by Akinkunmi (1999) which is as a result of family background, perception, situation, environment and peers influence. However, in the views of Williams (2009) out of the elements involved in the worker expectations salary and benefits are obvious compensations that an employee expects from his or her employer but there are a host of immaterial things that can provide job satisfaction. To Nicolaides (2002) in Balogun (2004), expectations have a powerful impact on emotions, behaviours and most especially in the worker's performances which is deeply rooted in communication of work expectations to new and old employees as many of these expectations are not written anywhere thus giving room for speculations and figment of imaginations. This view was buttress by Ayinla (2006) when he asserted that people who have clearly defined and well communicated expectations enjoy greater job satisfaction than those whose expectation go unspoken, unrealised or met.

\subsection{Statement of the Problem}

Over the years, it has been a general belief that every individual is an apostle of expectations in all ramifications of life whether it is work activities or leisure activities as long as it involves human endeavours (Oginni \& Faseyiku, 2007). It is then logical to say that every 
employee has expectation which is pivotal to the source of employee's motivation, attitudes, feelings and behaviours as well as serving as a catalyst to performance. Employees have expectations for their careers and the organisation for which they work, there is need therefore that employers should match organisational expectations and opportunities with employee skills, talents and expectations. To match employee needs with organisational expectations, it is contingent upon the understanding of motivations, desires as well as preferences of each employee therefore, making work to be a satisfying and positive experience for employees when their work expectations are being met along organisational expectations. In Nigeria, Today's workplace demands high work performance from the employees although this does not suggest that work is put ahead of everything, it rather shows the competitiveness of work organisations and the need to retain committed, satisfied and productive employees through the balance of work life and personal life. However, what happens when there are discrepancies in work life and personal life i.e. expectations are continually abused, expectations are continuously at variance and unrealistic expectations through biases in perception on job satisfaction. These can become the catalyst of unrest and great unhappiness.

\subsection{Objective of the Study}

The study examined the role of employee's expectations in job satisfaction and labour turnover in the service industry in the Western Nigeria. This was achieved through the following specific objectives which were used as guild to navigate into the research focus;

1) To identify employee's expectations in the workplace vis-a-vis job satisfaction and labour turnover.

2) To identity major challenges in employees' expectation and job satisfaction.

3) To examine significant relationship between employee expectations and job satisfaction as well as labour turnover.

4) To determine the extent of relationship between employee expectation and job expectation as well as labour turnover.

\subsection{Research Questions}

Emerging from the statement of problem which is deeply rooted in the objective of the study gave rise to the following questions;

1) What are the basic elements of employee's expectations in the workplace vis-a-vis job satisfaction and labour turnover?

2) What are the major challenges in employee's expectation and job satisfaction?

3) Is there significant relationship between employee's expectations and job satisfaction as well as labour turnover?

4) What is the extent of relationship between employee's expectation and job expectation as well as labour turnover? 


\subsection{Scope of the Study}

The area of study was employee's expectations and job satisfaction with implications on the labour turnover. The data used for the research paper were obtained from the employees in the service industry in Western part of Nigeria that has six different states (Lagos, Ogun, Oyo, Ekiti, Ondo and Osun) out of which three states (Lagos, Ogun and Oyo) were actually used as the focus of the study.

\section{Literature Review}

\subsection{Work Expectations (Employee and Employer)}

According to Ayinla (2006) the expectations in the workplace are mutually exclusive between employees and the employers but the dynamism involved in these expectations is however different. In the views of Greene in Ayinla (2006) the expectations of employers are relatively static and stable across the nature of the organisations and businesses which revolves around and established in a variety of ways, including well-written company handbooks, clear job descriptions, work schedules, rules and job standards that need to be met for business to run smoothly and profitably. However, the expectations of workers are not static nor stable because the work expectations is a function of many variables such as personality, work experience, family background, culture, situation as well as peer influence (Akinkunmi, 1999; Okwonsor, 2007). All these put together will definitely determine the level of premium placed on the inherent elements of employee's expectation such as commensurate pay with performance, opportunities for training and development, opportunities for promotion, recognition for innovation or new idea, interesting tasks, dignity and respectful treatment, attractive benefits package, reasonable job security, loan facility, power and authority, a pleasant and safe working environment as well as quality of working life (Ayinla, 2006). Okwonsor (2007) assertion supported the views of Ayinla (2006) that all employees have expectations that they want their employer to meet in the course of employment and in the same vein, all employers have expectations that they want employees to meet which is visible and made available to employees for better understanding of work situation. On many occasions, the work expectations of employees do not have a clear-cut yardstick as what an individual perceived as work expectations today if the same individual is asked tomorrow the list is at variance again Baker (1996).

In a typical employment situation, there are certain expectations that are clearly understood by both employer and employee (Adeoye, 2005), the fact that the list of work expectations on the part of employees is in exhaustive; there is still a common level of expectations that provided a leverage to match the employee's expectation with that of the employers thus enable the two parties to work harmoniously such as job security, training and development, welfare package, safety in workplace, loyalty and integrity as well as punctuality (Momud, 2010). In the views of Momud (2010), this is the basic work expectations at the point of hiring a new employee into the organisation by the employers so also is the basis for acceptance of employment offers decision. He went further to add that it is after these basic needs (work expectations) are met that other forms of work expectations might come up most especially in the developing countries which would therefore determine the emerging trends 
of activities in the organisation with respect to expectations from both parties (employees and employer). Akinkunmi (1999) opinion was in support of this, when he asserted that the knowledge of the basic work expectations by employer and employee will open the door to mutual understanding, identify their expectations and discover which expectations they consider most important, get feedback on how to communicate their expectations to others, take steps to get their expectations met. It will also adjust their expectations when appropriate, improve their outlook and enhance their attitude toward work, enjoy the benefits of increased job satisfaction and improved performance.

\subsection{Job Satisfaction}

Emanating from this, is recourse to the statement credited to Drucker in Obisi (1996) that communication is the only tool a manager (supervisor) has in order to carry out the assigned responsibilities since management is all about getting things done through other people. The inference here is that the communication is the chief obstacle to work expectations to meet the desired result as highlighted by Akinkunmi (1999), if it is used adequately the level of satisfaction derivable from job will be high and if otherwise the satisfaction level will be low. Although Mullins (2002) was of the opinion that job satisfaction is an emotional, a feeling, an attitude and a matter of perception thus, making it a complex concept that is difficult to measure objectively. Egan, Yang, \& Bartlett (2004) described job satisfaction as employee's affective reactions to a job based on comparing desired outcomes with actual outcomes. Bassett (1994) opined that the level of job satisfaction is affected by a wide range of individual, social, organisational and cultural variables. Others include alienation at work, state of information technology, job design and stress at work while Mullins (2002) added organisational and environmental factors to this. In the work of Mumford (1991) in a related area, employee's job satisfactions were examined in two ways of which what the organisation requires and what the employee is seeking is one of the two ways i.e. work expectations. He concluded by identifying five contractual areas namely the knowledge contract, the psychological contract, the efficiency of reward contract, the ethical contract and the task structure contract to be the factors that would determine the degree or level of job satisfaction. The deductive implication here is that when several of these expectations are not met at a bearable minimum level, job dissatisfaction is often the result manifesting in form of work alienation, frustrations, absenteeism, self-estrangement and dispensary visit (Fajana, 2002). Chen, Chang \& Yeh (2004) in his work on job satisfaction found that the larger the gap between career development program and career needs, the lower the job satisfaction. They revealed further that whenever the career development programs provided by their employers fail to satisfy employee's career needs and goals, their stress level increases. If this widening gap not timely addressed, it will lead to growing levels of employee dissatisfactions and thus lead to negative work attitudes which will ultimately lead to labour turnover. The views of Egan et al. (2004) supported the outcome of the findings of Chen et al. (2004) that when the accumulation of unmet expectations becomes sufficiently large, there is less job satisfaction and greater probability of withdrawal behaviour. 


\subsection{Labour Turnover}

Consequent upon these manifestations is labour turnover which is of two dimensions i.e. voluntary and involuntary labour turnover. The literary meaning of labour turnover is the rate of movement by which employees come into/leave the organisation. It is contingent upon the belief and assumption that for every employee that leave the organisation another employee is recruited to replace the employee leaving (Graham, 1989). The voluntary reasons are usually associated with employee's decision to quit an organisation while the involuntary reasons are also associated with dictate of the environment as well as the decision of employer to get rid of employee who is judged by the employer not to meet their work expectations (Oginni \& Faseyiku, 2012). The work of Elsdon and Iyer (1999) on related matter indicated that increase in value of human capital through training and education encourages employee to leave which shows that job dissatisfaction leading to labour turnover may not be totally supported by empirical research. Steers (1977) had a similar finding in his study of committed employees and organisation labour turnover that the more committed an employee is, the less of a desire they have to terminate from the organisation which means commitment in terms job satisfaction is significantly and inversely related to employee's turnover. Lincoln and Kalleberg (1996) however, sum up all the intrinsic and extrinsic elements involved in labour turnover to be classified into two categories i.e. pull and push factors. The pull factors are the factors within the organisation that make employee to leave and the push factors are the factors outside the organisation compelling employees to leave the organisation. The observations of Obisi (1996) and Fajana (2002) however, differ with reference to the peculiarity in the business environment in Nigeria when it was concluded in their separate findings that the unemployment situation in the country (Nigeria) has limited the work expectations on the part of the employees to job security at the expense of other intrinsic elements of work expectations while employer is constantly putting pressure on work performance from the entire workforce with or without reference to the likelihood expectations from the employees. The implication of these findings was that work expectation has nothing to do with job satisfaction in the wake of unemployment.

On the basis of the above literature review, the following model in form of diagram is developed by the authors;

\section{Organisation with a well defined formal communication structure with respect to work expectations}

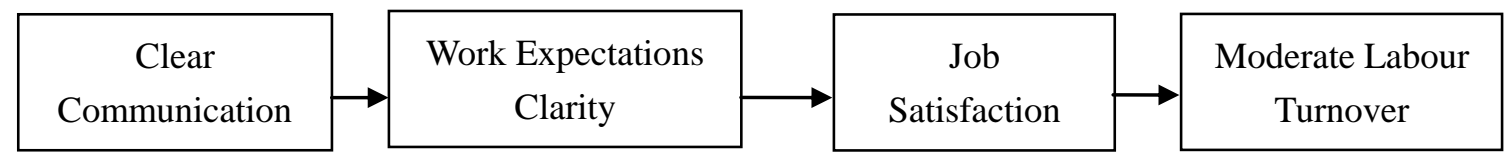

Source: developed by the Authors. 
Organisation without a well defined formal communication structure with respect to work expectations

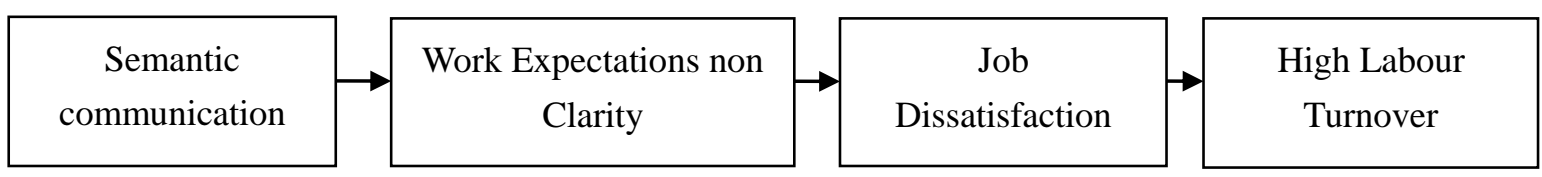

Source: developed by the Authors.

The above diagram is used to buttress the position of Akinkunmi and Drucker on the importance of communication in the workplace most especially in the area of clarity of purpose.

\subsection{Hypotheses}

The under listed hypotheses were formulated as a follow up to the review of the literature and the model developed by the authors;

1) There is no relationship between work expectations and job satisfaction.

2) There is no relationship between job satisfaction and labour turnover.

3) Work expectations do not have relationship with job satisfaction and labour turnover

\section{Methodology}

This was a survey study and made use of primary and secondary data. The secondary data explored the works of other scholars in the related work area in order to give direction, comparison and verify their claims through documented information and questionnaire was used as primary source of data to elicit relevant information that was used to test the above stated hypotheses. The questionnaire has five (5) questions on each of the variables (work expectations (independent), job satisfaction (intervening variable) and labour turnover (dependent)) which were designed to investigate the connection of these variables. Aside the bio data questions, there were fifteen (15) questions in all and the constructs in each of the variables were adopted from prior studies which were streamlined to fit into Likert 5point rating of measurement scales where strongly agree $=5$, agree $=4$, neutral $=3$, disagree $=2$ and strongly disagree $=1$. Items for measuring work expectations have been adopted based on Ahmad and Schroeder's (2003) studies and items for measuring job satisfaction were adapted from the Minnesota Satisfaction Questionnaire by Weiss (1967) and Heinonen and Korvela's (2003) studies while the items for measuring labour turnover were adapted from the Schwepker and Charles' (2001) studies. The overall reliability co-efficient of the instrument yielded an $\mathrm{r}=0.87$ Cronbach Alpha.

The population of the study was service industry in Lagos state, Ogun state and Oyo state all are some of the states in Southwestern part of Nigeria. Among various service organisations in the focus of study, a total number of 20 service organisations were purposively selected because of the large number of service organisation and high labour turnover in the area. Pilot study was used to choose 10 organisations from Lagos state, 6 organisations from Ogun state 
and 4 organisations from Oyo states with 847 employees out of which 593 respondents were chosen as the sample size using Yamen's formula representing 70\% of the population. Stratified random sampling technique was used to administer 593 copies of questionnaires from which 571 copies were collected back from the respondents but 542 responses were found useful for analytical purposes thus giving response rate as $91 \%$. Data collected were analysed through the use of frequency and distribution table, descriptive and inferential statistics such as mean, standard deviation, correlation and regression analyses were also used with the help of SPSS.

\section{Data Analysis and Interpretation}

Demographic information about the respondents' responses $(\mathrm{N}=542)$

Table 1. Age characteristics of the respondents

\begin{tabular}{|c|c|c|}
\hline Age Variables & Frequency & Percentage \\
\hline Less than 25 & 51 & 9.41 \\
$25-35$ & 73 & 13.47 \\
$36-45$ & 275 & 50.74 \\
$46-55$ & 107 & 19.74 \\
55 and above & 36 & 6.64 \\
Total & $\mathbf{5 4 2}$ & $\mathbf{1 0 0}$ \\
\hline
\end{tabular}

Source: Questionnaire Survey 2016.

From the above table 1, it shows that 275 respondents were within the age bracket of $36-45$ years representing $50.74 \%$ while 107 respondents were also within the age bracket of $46-55$ years representing $19.74 \%$. The proportion of the respondents signified that the majority of them are matured and understood what their expectation should be in any work situation. This was followed by age with the bracket of 25 - 35 years 73 respondents representing $13.47 \%$, below the age bracket 25 were 51 respondents representing $9.41 \%$ and above 55 age bracket were 36 respondents with $6.64 \%$ in all the respondents were matured and with recourse to the age bracket that was below 25, in Nigeria age 25 is seen to be quite matured with high degree of freedom.

Table 2. Gender characteristics of the respondents

\begin{tabular}{|c|c|c|}
\hline Gender Variables & Frequency & Percentage \\
\hline Male & 329 & 60.70 \\
Female & 213 & 39.30 \\
Total & $\mathbf{5 4 2}$ & $\mathbf{1 0 0}$ \\
\hline
\end{tabular}

Source: Questionnaire Survey 2016. 


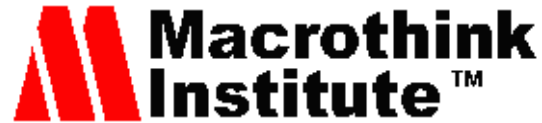

Table 2 indicated the gender proportion which shows that majority of the respondents were male with 329 representing $60.70 \%$ while female respondents were 213 representing $39.30 \%$. The significance of the gender information was that the society (Nigeria) placed high premium on men with respect to meeting the immediate needs of both nuclear and extended family this would definitely define the trends of work expectations of male respondents while female respondents work expectations are equally decided by the same factors. The percentage of the proportion also indicated that the work environment of these service organisations is not completely dominated by their counterparts.

Table 3. Length of service characteristics of the respondents in their present organisation

\begin{tabular}{|c|c|c|}
\hline Length of Service Variables & Frequency & Percentage \\
\hline Less than 3 years & 194 & 35.79 \\
3- 5 years & 228 & 42.07 \\
6 - 10 years & 89 & 16.42 \\
11yrs and above & 31 & 5.72 \\
Total & $\mathbf{5 4 2}$ & $\mathbf{1 0 0}$ \\
\hline
\end{tabular}

Source: Questionnaire Survey 2016.

The table 3 showed that the majority of the respondents have spent between 3-5 years with 228 representing $42.07 \%$ followed by those that have less than 3 years with 194 respondents representing $35.79 \%$ while 89 respondents representing $16.42 \%$ were with $6-10$ years length of service in the organisation and 31 respondents representing $5.72 \%$ were with 11 years and above stay in their respective organisation. The implication of this information was to provide insight on the movement of the respondents which is a function of many variables, it can be deduced that the employee's mobility in the service industry is relatively unstable as the majority of the respondents' length of service ranged between less than 3 years to 5 years totalling to 422 respondents with $77.86 \%$ the highest combined responses aside the category in the organisation.

Table 4. Work experience characteristics of the respondents

\begin{tabular}{|c|c|c|}
\hline Work experience Variables & Frequency & Percentage \\
\hline Less than 5 years & 105 & 19.37 \\
5- 10 years & 223 & 41.14 \\
11 - 15 years & 179 & 33.02 \\
16 yrs. and above & 35 & 6.46 \\
Total & $\mathbf{5 4 2}$ & $\mathbf{1 0 0}$ \\
\hline
\end{tabular}

Source: Questionnaire Survey 2016. 


\section{MInstitute Macrothink}

World Journal of Business and Management

ISSN 2377-4622

2018, Vol. 4, No. 1

Table 4 has information about the work experience ranging from under 5 years to 16 years above. The majority of the respondents have between 5 - 10 years work experience with 223 respondents representing $41.14 \%$, followed by work experience between 11 - 15 years with 179 respondents representing 33.02\% while 105 respondents were with less than 5 years work experience representing $19.37 \%$ and 35 respondents were with 16 years and above. The information obtained here is sequel to the above deduction as the majority of the respondents were with work experience ranging from 5-10 years which revealed there is movement on the part of the respondents as the work experience is acquired outside their present place of work. The chief reason for the movement is traceable to their expectation from work employment.

Table 5. Educational qualifications of the respondents

\begin{tabular}{|c|c|c|}
\hline Educational levels Variables & Frequency & Percentage \\
\hline Master's degree holders & 83 & 15.31 \\
Bachelor's degree holders & 205 & 37.82 \\
Professional membership & 85 & 15.68 \\
Diploma certificates & 169 & 31.18 \\
Total & $\mathbf{5 4 2}$ & $\mathbf{1 0 0}$ \\
\hline
\end{tabular}

Source: Questionnaire Survey 2016.

Table 5 furnished information about the educational levels of the respondents which showed that the majority of the respondents were university graduates with 288 (master and bachelor degree) representing 53.13\% although out of this figure, 205 respondents representing $37 \%$ which was less than $40 \%$ of the total respondent have first degree (bachelor) while 83 respondents with $15.31 \%$ were holders of second degree (master). It can then be deduced that out of the university graduate respondents about half have compound qualification and it was followed by holders of professional membership with 85 respondents representing $15 \%$ while 169 respondents were holders of diploma certificates. The overall implication of the information sought here was to verify the depth of knowledge and understanding of the respondents towards the questions contained in the questionnaire and probably deduce if the level of education is potential source of dissatisfaction and labour turnover.

Table 6. Marital status of the respondents

\begin{tabular}{|c|c|c|}
\hline Marital Status Variables & Frequency & Percentage \\
\hline Single & 98 & 18.08 \\
Married & 404 & 74.54 \\
Widowed & 31 & 5.72 \\
Divorced & 9 & 1.66 \\
Total & $\mathbf{5 4 2}$ & $\mathbf{1 0 0}$ \\
\hline
\end{tabular}

Source: Questionnaire Survey 2016. 


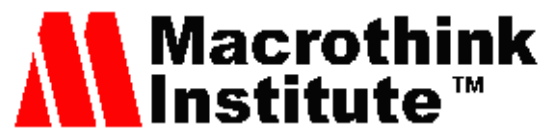

World Journal of Business and Management

ISSN 2377-4622

2018, Vol. 4, No. 1

Table 6 showed the five (5) categories of marital status although the fifth one was not recorded because there was no response which was widower and others were as tabulated above. It showed that 404 respondents representing 74.54\% were married followed by 98 respondents who were singles representing $18.08 \%$ while 31 respondents representing $5.72 \%$ have lost their husbands for reasons not stated and 9 respondents representing $1.66 \%$ were divorced. The information provided clearly pointed to the maturity and emotional stability of the respondents as marriage is considered as of paramount importance in Nigeria.

Table 7. Category of the respondents in the organisation

\begin{tabular}{|c|c|c|}
\hline Variables & Frequency & Percentage \\
\hline Top management level & 23 & 4.24 \\
Middle management level & 321 & 59.23 \\
Low management level & 182 & 33.58 \\
Others & 16 & 2.95 \\
Total & $\mathbf{5 4 2}$ & $\mathbf{1 0 0}$ \\
\hline
\end{tabular}

Source: Questionnaire Survey 2016.

Table 7 provided information about the categories of the respondents in the organisation where 23 respondents representing 4.24\% were among the top management level and 321 respondents were in the middle management level representing 59.23\% followed by low management level with 182 respondents representing $33.58 \%$ while 16 respondents were outside the managerial levels. The clear indication here was that majority of the respondents were in the middle management level thus implying that the respondents have a clear picture of what work expectations should be vis-a-vis their satisfaction on the job.

Table 8. Correlation of relationship between work expectations, job satisfaction and labour turnover at 0.05 level of significance - (2- tailed test)

\begin{tabular}{|c|c|c|c|c|c|c|}
\hline \multicolumn{7}{|c|}{ Correlation of the relationship } \\
\hline Variables & $\mathrm{N}$ & Mean & $\begin{array}{c}\text { Standard } \\
\text { Deviation }\end{array}$ & $\begin{array}{c}\text { Work } \\
\text { Expectations }\end{array}$ & $\begin{array}{c}\text { Job } \\
\text { Satisfaction }\end{array}$ & $\begin{array}{c}\text { Labour } \\
\text { Turnover }\end{array}$ \\
\hline Work expectations & 542 & 4.06 & 0.79 & 1 & 0.914 & 0.953 \\
\hline Job satisfaction & 542 & 3.45 & 1.02 & 0.914 & 1 & 0.987 \\
\hline Labour turnover & 542 & 4.14 & 0.80 & 0.953 & 0.987 & 1 \\
\hline
\end{tabular}

Source: Result of analysis of data obtained by survey questionnaire 2016 through SPSS.

Table 8 has the result of correlation from the above analysis through SPSS showed that there is a bond in form of relationship that is positive among the independent variable and dependent variables which is significant i.e work expectation and job satisfaction is $r=0.914$, 
$\mathrm{p}<0.05$, job satisfaction and labour turnover is $\mathrm{r}=0.987, \mathrm{p}<0.05$ while work expectation and labour turnover is $r=0.953, p<0.05$. Out of these, the relationship between job satisfaction and labour turnover was the highest $(r=0.987, \mathrm{p}<0.05)$ suggesting that job satisfaction is a good predictor of employee's decision to stay or leave an organisation and this was followed by the relationship between work expectation and labour turnover $(r=0.953, p<0.05)$ suggesting also that when workers expectation are met the outcome may be the decision to stay on in the organisation while work expectation and job satisfaction relationship $\mathrm{r}=$ $0.914, p<0.05$ is next in that order which also imply that there will be job satisfaction where work expectation is met.

Table 9. Result of regression analysis through SPSS

\begin{tabular}{|c|c|c|c|c|}
\hline Variables & \multicolumn{4}{|c|}{ Coefficient } \\
\hline & Beta & $\mathrm{F}$ & $\mathrm{R}^{2}$ & $\mathrm{~N}$ \\
\hline Work expectation & 0.914 & 1.572 & 0.825 & 542 \\
\hline Job satisfaction & 0.987 & 3.432 & 0.876 & 542 \\
\hline Labour turnover & 0.953 & 1.250 & 0.811 & 542 \\
\hline
\end{tabular}

Source: analysis of survey questionnaire 2016 through SPSS.

Table 9 has the result of the regression analysis of the variables involved in the research work i.e work expectation, job satisfaction and labour turnover. It was evident that work expectations had momentous significant influence on job satisfaction because $\mathrm{R}=0.914$, $\mathrm{R}^{2}=0.825$ and Fcal $=1.572$ at $5 \%$ level of significance which imply that there is positive correlation between work expectations and job satisfaction and $\mathrm{R}^{2}$ showed that work expectations had been able to explain $82.5 \%$ of the total variation in job satisfaction while the remaining $17.5 \%$ had been explained by other variables not mentioned in the model, thus confirming that the linear relationship is strong and positive i.e an increase in work expectations would bring about an in job satisfaction while the Fcal $=1.572$ which is greater than the Ftab which is 1.190 thus implying that the null hypothesis is rejected and the alternative is accepted.

The same table 9 also confirmed that job satisfaction is positively correlated with strong significant influence on labour turnover where $\mathrm{R}=0.987, \mathrm{R}^{2}=0.876$ and Fcal $=3.432$ at 0.05 level of significance. The $\mathrm{R}$ value of 0.987 showed that the linear relationship is positive and strong while $\mathrm{R}^{2}=0.876$ indicated that job satisfaction had explained $87.6 \%$ of the total variation in labour turnover while the remaining $12.4 \%$ had been explained by other variables not mentioned in the model. The Fcal is also greater than Ftab i.e Fcal $=3.432<$ Ftab $=1.190$ which translate to rejecting the null hypothesis and accept the alternative hypothesis i.e job satisfaction has relationship with labour turnover. The case of hypothesis three (3) was also confirmed to indicate positive relationship among the variables involved in the hypothesis i.e work expectation plays a significant role in the employee's decision in respect of what constitute job satisfaction and factors dictating their mobility. 


\subsection{Discussion of Findings}

The demographic information obtained from the respondents revealed clearly that the respondents were matured, educated and experienced to understand what their work expectation is all about as well as what constitute job satisfaction and implication on labour turnover. The result obtained through the use of SPSS to validate the proposition which were contained in the stated hypotheses showed that there was strong relationship and significant correlation between work expectation and job satisfaction which implies that if work expectation is met it would bring about a corresponding value in the level of job satisfaction derivable from the workplace and if it is not, the same would be the level of job satisfaction (dissatisfaction). This result of the outcome of the research work is in an agreement with the positions of Akinkunmi (1999) and Ayinla (2006). The views of Akinkunmi (1999) was that employees have their expectations from work and that employer should endeavour to communication their expectation which would provide opportunity for employees to adjust and exhibit appropriate work attitude and behaviour that bring about increase in job satisfaction and improved work performance while Ayinla (2006) was of the opinion that the quality of work expectation would determine the quality level of job satisfaction since work expectation is a function of the individual personality, work experience, family background, culture, situation as well as peer influence (Okwonsor, 2007).

With respect to job satisfaction and labour turnover, table 8 and 9 clearly indicated that there was a strong coherence relationship between job satisfaction and labour turnover where a high degree of percentage of job satisfaction explained the underlining reasons in employee's decision to leave or join another organisation. This was also supported by the views of Mumford (1991) that the satisfaction of the identified contractual areas would determine the degree or level of job satisfaction with final analysis on labour turnover, Fajana (2002), asserted that when the job satisfaction is high and labour retention is also high and vice versa. He however cautioned that this linear relationship between job satisfaction and labour turnover may not always valid because sometimes job dissatisfaction may not bring about high labour turnover in an environment that is characterised by unemployment and Chen etal (2004) opined that when the accumulation of unmet expectations becomes sufficiently large, there is less job satisfaction and greater probability of withdrawal behaviour. With respect to hypothesis three (3), it was clear from the above analysis and overall discussions that the relationship among the variables were positive and proven to be highly significant which implies that work expectations involvement in job satisfaction and labour turnover was very high. In the same vein, job satisfaction can also be deduced to be a moderating factor between work expectations and labour turnover. i.e job satisfaction is the outcome of work expectations and whatever be the degree of job satisfaction the influence is always significant as determinant of labour turnover (Kohler \& Mathieu, 1993; Saari \&Judge, 2004). It was also discovered that communication is the major challenge is work expectation which was built on the premise that if it is well utilised the result would be positive and if otherwise, the consequent is always enormous (Akinkunmi, 1999). 


\section{Conclusion and Recommendations}

The focus of the research paper was to investigate the role of work expectations from employees' perspective with respect to their job satisfaction vis-a-vis labour turnover with a view to identifying inherent elements of work expectation and determine the extent of relationship among the component variables. The study disclosed a comprehensive and robust relationship between work expectations and job satisfaction, between job satisfaction and labour turnover and among the independent variable and dependent variables. The following were identified as the inherent elements of work expectations commensurate pay with performance, opportunities for training and development, opportunities for promotion, recognition for innovation or new idea, interesting tasks, dignity and respectful treatment, attractive benefits package, reasonable job security, loan facility, power and authority, a pleasant and safe working environment as well as quality of working life. It was also found that work expectations remained the strongest variable among other variables that influences the job satisfaction to determine the trend of labour turnover while job satisfaction was also found to be a mediator between work expectation and labour turnover which implies that job satisfaction is contingent upon work expectation and invariably determine the rate of labour turnover. It can therefore be stated that work expectations play a significant and dominant role in enhancing job satisfaction of employees as well as increasing employees' retention which will bring out stability in the workforce and invariably usher in goodwill that will enhance the image of the organisation with impact on delivery of service.

It is recommended that the management of the organisations in the service industry should endeavour to utilise interview as a weapon during employment process to understand the work expectations of the employees and place side by side with that of employer's expectations where the job is then given to the most suitable candidate and not the best candidate whose work expectation is not congruent with that of the employer. High premium should be placed on communication structure to facilitate quick dissemination of information with commensurable feedback flow of correspondence to avoid giving credence to rumour spreading that may not profit the organisation. The personnel department should be empowered to gauge from time to time the tension temperature in order to measure the level of satisfaction most especially reactions of employees to old and new personnel policies vis-a-vis incidents in the business environment. Finally, policies and environment should be created to support job security so as to enjoy maximum cooperation from employees since it is the desire of every employee to have secured job which is a challenge in an unemployment situation as evident in Nigeria at present.

\section{References}

Adebanjo, K. K. (2003). Introduction to Business Management (4th ed.). Ilorin, kwara State: Hamzat printing press.

Adeoye, A. A. (2005). The Art of Managing Business and People in Nigeria. Petman Enterprises Ltd. Somolu Lagos.

Adeoye, A. A., \& Williams, S. J. (2007). Human Resources at Work; A new dimension in 
Business Organisation. Lagos: Peacock Publishing.

Ahmad, S., \& Schroeder, F. G. (2003). The Impact of Human Management Practices on Operational Performance; Recognising Country and Industry Differences. Journal of Operational Management, 21, 19-43. https://doi.org/10.1016/S0272-6963(02)00056-6

Akinkunmi, M. S. (1999). Introduction to Personnel Psychology; An industrial perspective. Leadway Ltd, Lagos.

Ayinla. (2006). Strategic Human Resource Management, A Process Approach. Mulink Publishing House, Lagos.

Baker, H. G. (1996). The psychological contract between employer and employee. Journal of Psychology, 33(3), 16-30.

Balogun, S. K. (2004). Fundamentals of Human Resources Management (3rd ed.). Alakia, Ibadan: Adeoloja Press.

Bassett, G. (1994). The case against Job Satisfaction. Business Horizons, 37(3), 61-68. https://doi.org/10.1016/0007-6813(94)90007-8

Chen, T. Y., Chang, P. L., \& Yeh, C. W. (2004). A study of Career Needs, Career Development programs, job satisfaction and the turnover intentions of R\&D Personnel. Career Development international, $\quad 9(4), \quad 424-437$. https://doi.org/10.1108/13620430410544364

Egan, T. M., Yang, B., \& Bartlett. (2004). The Effects of Organisational Learning Culture and Job Satisfaction on Motivation to transfer learning and organisational commitment. Human Resource Development Quarterly, 15(3), 279-301. https://doi.org/10.1002/hrdq.1104

Elsdon, R., \&Iyer, S. (1999). Creating Value and enhancing Retention through Employee Development; the sun micro-system experience. Human Resource Planning, 22(2), 39-48.

Fajana, S. (2002). Human Resource Management, An introduction. Labofin and company, Lagos.

Graham, H. T. (1989). Human Resources Management, $M \&$ E Handbooks on Business and Management (6th ed.). London: Pitman Publishing.

Hoinonen, J., \& Korvela, K. (2003). How About measuring Intrapreneurship? EISB Conference, Milan.

Kohler, S. S., \& Mathieu, J. E. (2003). An Examination of the relationship Between Affective Reactions, Work Perceptions, Individual Resource Characteristics and Multiple Absence Criteria. Journal of Organisational Behaviour, 11, 515-530.

Lincoln, J. R., \& Kalleberg, A. L. (1996). Commitment, Quits and work organisation in Japanese and US plants. Industrial and Labour Relations Review, 50(1), 39-59. https://doi.org/10.1177/001979399605000103

Momud, I. K. (2010). Human capital management in the $21^{\text {st }}$ century; A Practical Approach. 
Lagos: Lafgay Publishing.

Mullins, J. L. (2002). Management and Organisational Behaviour (6th ed.). Prentice-Hall, Italy.

Mumford, E. (1991). Job Satisfaction; A method of Analysis. Personal Review, 20(3), 11-19.

Obisi, C. (1996). Personnel Management. Jackboot Enterprises, Ojokoro Layout, Agbowo Ibadan, Oyo.

Oginni, B. O., \& Faseyiku, I. O. (2007). Dynamics of Industrial Relations. Mankore Print Ltd, Somolu - Lagos.

Oginni, B. O., \& Faseyiku, I. O. (2012). The Dynamics of Industrial Relations. Lagos: Mankore prints.

Okwonzor, K. P. (2007). Human Resources Management in Action. Abeokuta: Afamt Printing Press Ltd.

Saari, L. M., \& Judge, T. A. (2004). Employee Attitudes and Job Satisfaction. Human Resource Management, 43(4), 395-407. https://doi.org/10.1002/hrm.20032

Schwepker, Jr., \& Charles, H. (2001). Ethical Climate's Relationship to Job Satisfaction, Organisational Commitment and Turnover in the Sales force. Journal of Business Research, 54, 39-52. https://doi.org/10.1016/S0148-2963(00)00125-9

Steer, R. M. (1977). Antecedents and outcomes of organisational commitment. Administrative Science Quarterly, 22(1), 46-56. https://doi.org/10.2307/2391745

Weiss, D. J. (1967). Manual for the Minnesota satisfaction Questionnaire, Minnesota Studies in Vocational Rehabilitation. University of Minnesota.

Williams, S. J. (2009). A Study of Workplace Motivation and Labour Turnover in the Public Sector of Nigerian Economy. Journal of Business Management and Economics, 6(5), 34-41.

\section{Copyright Disclaimer}

Copyright for this article is retained by the author(s), with first publication rights granted to the journal.

This is an open-access article distributed under the terms and conditions of the Creative Commons Attribution license (http://creativecommons.org/licenses/by/3.0/). 